\title{
Study on the Model of Lesson Study-Based Handicraft Job Trainingin ECO Green Park Kota Batu
}

\author{
Siti Zahro ${ }^{1}$, Eddy Sutadji², and Titi Mutiara Kiranawati ${ }^{2}$ \\ ${ }^{1}$ Magister Student in Vocational Education Department, State University of Malang, Indonesia \\ ${ }^{2}$ Senior Lecturer in Vocational Education Department, State University of Malang, Indonesia \\ sitizahrovivi@gmail.com
}

\begin{abstract}
The aim of this research is to provide information about the model of lesson study-based handicraft job training among the employees of ECO Green Park in guiding the visitors in their workplace. The research method applied was a descriptive method with a qualitative approach. Meanwhile, the population involved in this research was the employees of ECO Green Park in Department of Marketing, Fun and Game, Animal, Science Center, Chief Accounting, Public Area, gardener, Engineering and F\&B. The type of sample used was a random sampling with the involvement of 65 persons. The technique in collecting data was conducted through questionnaire, interview and observation. The data analysis used here was in the form of a frequency distribution with an SPSS program for Windows version 21. The result of this research then shows a need of the employee for training materials to support their work. In addition, training facilities to support the achievement of training implementation and strategy in delivering the training materials are deemed essential to be a concern. Meanwhile, the evaluation of the training program was performed using the Kirkpatrick model highly suitable to measure the effectiveness of the training program at ECO Green Park.
\end{abstract}

Keywords: Job Training, handicraft, ECO Green Park

\section{Introduction}

Education in Indonesia is implemented through 3 (three) courses - formal education, non-formal education and informal education. Formal education refers to the education that consists of three levels, viz. Primary education, intermediate education and higher education. Non-formal education, meanwhile, is the education held by community with the purpose of improving the competency of learners systematically and gradually. The education unit of non-formal education might include courses, training center, study group, community center, majelis ta'lim (informal gathering) and other equivalent education units. The informal education then is the education held by family and environment in the form of independent learning activities. Such education is held in the family (Regulation of National Education System, 2003; SNP, 2006).

One of the interesting and unique non-formal educations can be found in a touristy place named ECO Green Park. It is an education-based tourism place. It provides a number of modes that can be used as an entertainment that also contains educational and training values. It has been figured out from the initial observation conducted by the researcher that the purpose of facilitating the education and training for society, as explained by the Operational Manager of ECO Green Park in Kota Batu, East Java Province, is to broaden the knowledge and skill not only obtained in formal education (school). In fact, education and training that are currently only able to be obtained in formal school also can be done at tourism sites supported by both please situation and environment conditioned as a learning and entertainment media. For this, ECO Green Park of Kota Batu has a motto "Fun and Study" that invites the visitors/learning participants to study comfortably through an environment that has been made in such a manner, thus emerging a fun learning and training process. The learning and training environment will be more optimal in its objective achievement if it is supported by other components such as Human Resources both as a teacher and as a trainer, learning devices, and gradual guidance to enhance the work performance and motivation of Human Resource.

Based on the observation conducted by the researcher, it has been found that $99 \%$ of employees, in fact, do not have any formal education both as a teacher and as a trainer. To provide learning and training to the visitors/learners, the employees of ECO Green Park do it based on autodidact (self-taught). From the interview with some visitors/learners, it was observed that there was dissatisfaction of the visitors/learners towards the service on learning and training provided by the employees. This was in 
view of the lack of competence of the employees in both managing the learning and training and mastering the learning and training materials. As a consequence, the objective of the learning and training expected by the visitors/learners is not achieved optimally.

These issues then show how the employees are not ready in implementing the learning and training process in the mode location. This is also as a result of the absence of training and guidance program held by the management for the employees. In fact, the unpreparedness of the employees in ECO Green Park as an educator/trainer can be minimized through a gradual training. The training is to create the employees' competence since it becomes a tool to enhance the work performance of the employees; thus, it is critical to be done by any companies. Also, training can bring a positive impact on improving the competence of the employees (Hu, 2004; Salmah, 2012). Sultana, Irum, Ahmed, Mehmood(2012) also explained that training is required by the workers to sufficiently execute a task or job and to improve performance in the job environment as well as necessary to ensure an adequate supply of staff that is technically and socially competent and capable of career development into specialist departments or management positions. There is therefore a continual need for the process of staff development, and training fulfils an important part of this process due to training should be viewed therefore as an integral part of the process of total quality management that is done by management.

To cope with the issues, training can be held to build the competence of the employees in implementation of the learning and training to the aims and goals of the organizations(Sultana et. al, 2012) as well as making organizations more profitable (Ameeq \& Hanif, 2013). Work training that will be done is by providing the guidance and evaluation through discussion among colleagues and the inputs from the learning expert can bring a positive impact on building the competence of the employees (ILO, 2010). To make the learning and training more interesting, creative, and innovative, the model of work training that will be done is based on lesson study (Demir, Czerniak, \&Hart, 2013).

The model of lesson study based handicraft work training has been selected in consideration that it does not disturb the routine of the company such as the routine of the employees in providing a service for the visitors that want to learn (Willox, 2013). Besides, this model only requires a technical management in term of the preparedness in the implementation in accordance with the sets of equipment of lesson study needed such as model teacher, observer, and assessment instruments (Carrier, 2011). Actually, this model is identical with the on the job training model but it has an observer in charge of observing, evaluating and giving reflection on the learning process to make it more develops in creativity and innovation(Demir et. al, 2013).

\section{Review of Literature}

Job Training Model: Job Training model is suitable for building the competence of the employees since it can be applied towards the senior employees and the new ones. Also, this model can be applied without any disturbance to the activities of the employees (Kamil:2010).This is supported by the research of Muzaffar (2012) stating that job training is a good training in a company to enhance the commitment of the employees and to minimize the rate of the resign. The job training is a total of activities to give, obtain, enhance and develop the work competence, productivity, discipline, work ethos at certain skill and expertise level in accordance with the level and qualification of position and job (Government Regulation No. 31 Year 2006).

The implementation of the job-training model is due to improve the competence of the employees or labor in accordance with the need analysis. It also requires the correct phases. Gunn and Davies (2008) mentioned 5 phases of a systematic learning in training (SAT/Systematic Approach of Training), including: Phase 1, it is to do the analysis to develop a detail understanding from the task implemented by the employees and to analyze the form of competence needed to be given in the training to make the individual to be competent in implementing the task.Phase 2, this covers the design phase focused on the task development and the training purpose directly based on the competence of analysis in phase 1 . This phase will help to ensure that the training conducted will directly support the training participant towards the achievement of competence for their work. It is important to note, the background of the employees will determine the variety of competencies. Phase 3 , this is to make training plan and development including training materials that will be delivered in training. The materials delivered include the objective of the training, module/handout, evaluation method, and the organized competence assessment. Phase 4 , the delivery of the training to find out the identification of the needs. If this attempt of 
identification comes to the phase of development, the training must be delivered consistently and reliably to all training participants. Phase 5 , this phase covers the process review and the training management. It is used to control the expenditure and the resources of all training programs that have been agreed by management. By doing so, the results of the evaluation can be identified and used as the base of annual program on training development.

The success of the implementation of the model of job training certainly cannot be apart from the quality of the training. Australian National Training Authority/ANTA (2004) stated that a number of quality criteria of training include (1) the combination of basic materials in training; (2) the introduction of the training for the program of change; (3) the implementation of the training; (4) improved monitoring; (5) consulting, teaching and motivating the training participants and (6) evaluating the training participants. Kaswan (2013) and Daryanto (2014) also stated that the job training is more emphasized on the preparedness of the training (materials and facilities of its training), strategy in delivering the materials of the training (method, media and trainer) and evaluation of the training program.

Handicraft: Handicraft refers to a part of arts in craft and art emphasized on the handicraft and function to process the material frequently found in environment not only to be valuable but also to have aesthetic values. Craft can "derive" many knowledge in fine art for instance in the way of carving to create a product. It also more frequently follows the tradition from any inventions mostly found individually by an artist. It can be in the form of artwork from soil, cloth, metal, paper, or wood. Handwork is all of the human works requiring a specific skill in term of hand. Thus, it is frequently named as handicraft. Handiwork is produced through human skill in processing raw materials. It can be classified based on the purpose of the creation or use into the one that has some functions in practicality, aesthetics and symbol (Enget, et al., 2008:2).

The raw materials used in making handicraft can be obtained from the existing materials and found in environment such as the used things coming from organic or inorganic waste that can be recycled to be the things that have usefulness and high selling point (Setyoko, 2012). Utarini, et al. (2009) stated that the form of handicraft is the use of dried leaf waste to be created into home industry handicrafts using the waste of leaves as the materials such as toothpick box, tissue box, or other interesting decorations. Retnaningsih, et al. (2010) also explained that the use of the used plastic and bottle can be used as the interesting handicrafts. Wahyono \& Sudarno (2012) stated that the variety of the handicrafts from plastic wastes can be in the form of small butterfly brittle and beautiful lampion.

Lesson Study: Lesson study is a process of a model in giving guidance for educator through a collaborative and sustainable learning analysis based on the colleague principles to build community of learning (Riyanti, 2007; Susilo, 2013). Yoshida (2002) also explained that lesson study is a process that has been done by Japanese teachers to be involved in enhancing the teaching quality based on the experiences that they have given to the learners. Lesson study is performed in three phases including PLAN aimed to create a learning design that is believed to be capable of learning the learners effectively, DO means to implement the learning design that has been planned and reflection (SEE) aims to figure out the strengths and weaknesses in the learning implementation. Those three phases are repeatedly conducted (Guidance of the Lesson Study Implementation at LPTK, 2008).

ECO Green Park: ECO Green is a tourism place that is firstly developed by Park Group of East Java. It has an ecosystem nuance and environment packaged beautifully and internationally to attract the visitor to have a recreation. There are 35 modes that combine the concept of natural tourism, culture, environment and art that are inspiring, interesting and educative. The mission of ECO Green Park is to build a tourism destination supported with the nuance of green and fresh nature, good education concept oriented to environmental and renewable technology education, and the availability of education on wild-animal conservation without ignoring its function as a recreation place and the best entertainment alternative in Kota Batu, East Java. Hence, the slogan of ECO Green Park is Fun and Study.

\section{Methodology}

The research design here is descriptive with a qualitative approach.

Population and Sample: The population involved in this research was all employees in ECO Green Park. There were 78 people from a variety of departments, including Marketing, Fun and Game, Animal, Science 
Center, Chief Accounting, Public Area, Gardener, Engineering, F\&B. The type of sample used here, meanwhile, was random sampling; thus, the number of the sample was 65 persons.

Research Instrument: The instrument used in this research was questionnaires to measure the model of lesson-based handicraft job training at ECO Green Park, Kota Batu. Meanwhile, the variable measured was the training materials (10 items), training facilities (12 items), strategy in delivering the training materials (13 items) and evaluation of the training program (74 items).

Technique of Data Collection: The data were collected through the questionnaires distributed before and after the training to all participants of the training at ECO Green Park, Kota Batu. The interview and observation also were performed to support the questionnaires data.

Data Analysis: Data analysis used in this research was a descriptive statistics using SPSS Program for Windows in the version 21. The researcher has set five categories to determine the quality (good or poor) of research indicators, including very poor (0-1.9), less (2-2.9), fair (3-3.9), good (4-4.5), and very good (4.6-5) in the range of 1 to 5 . The lowest score of variables of training materials was 10 and the highest one was 50 .

\section{Result and Discussion}

\section{Result}

The result of the research on the model of lesson study based handicraft job training was found through the analysis on the sub-variables, including (1) training materials; (2) training facilities; (3) strategies in delivering the training materials and (4) evaluation of the training program.

Table 1: Distribution of the model of lesson study based handicraft job training

\begin{tabular}{lccccc}
\hline Sub-Variables & N & M & SD & Skew & Sek \\
\hline Research materials & 65 & 4,40 & 0,82 & -0.83 & -0.07 \\
Research facilities & 65 & 4,12 & 0.50 & 0.14 & -0.89 \\
Strategy in delivering training materials & 65 & 4,05 & 0.73 & 0.12 & -1.11 \\
Evaluation of training program & 65 & 4,20 & 0.65 & -0.64 & -0.57 \\
\hline \multicolumn{2}{c}{ N= Number, M= Mean, SD= Standard Deviation, Skew= Skewness, Sek= Kurtosis } \\
\hline
\end{tabular}

Table 2: The response of the participants, reliabilities, and validities of the model of lesson study based handicraft job training

\begin{tabular}{|c|c|c|c|c|c|c|c|}
\hline Sub-Variables & SK & $\mathbf{K}$ & C & B & SB & $\mathbf{V}$ & $\mathbf{R}$ \\
\hline Training Materials & - & - & - & $\begin{array}{l}9 \\
(13.8 \%)\end{array}$ & $\begin{array}{l}56 \\
(86.2 \%)\end{array}$ & 0.57 & 0.64 \\
\hline $\begin{array}{l}\text { Research Facilities } \\
\text { Strategy in Delivering the Training }\end{array}$ & - & - & $\begin{array}{l}17 \\
(26.2 \%)\end{array}$ & $\begin{array}{l}48 \\
(73.8 \%)\end{array}$ & - & 0.52 & 0.67 \\
\hline Materials & - & - & $\begin{array}{l}12 \\
(18.4 \%)\end{array}$ & $\begin{array}{l}53 \\
(81.6 \%)\end{array}$ & - & 0.55 & 0.68 \\
\hline Evaluation of the Training Program & - & - & - & $\begin{array}{l}7 \\
(10.9 \%\end{array}$ & $\begin{array}{l}58 \\
(89.1 \%)\end{array}$ & 0.61 & 0.65 \\
\hline
\end{tabular}

SD = Very Poor, K= Poor, C= Fair, B= Good, SB= Very Good=Validity, R= Reliability

Table 1 shows that the average values of model of Lesson Study Based Handicraft Job Training in ECO Green Park, KotaBatu were relatively good as supported by the average scores from the training material (4.40), the basic skill of handicraft in waste recycles (4.12), Strategy in delivering the training material (4.50), and evaluation of training program (4.20). Meanwhile, Table 2 depicts the validity score in the range of $0.52-0.61$ and the score of reliability in the range of 0.64 to 0.68 .

\section{Discussion}

Training Materials: Table 2 shows 56 participants (86.2\%) viewed that the materials of lesson study based handicraft job training at ECO Park, KotaBatu were very good and 9 participants (13.8\%) viewed it good. This result was showed by most of learning sources in the environment of ECO Green Park were made of waste-recycling process and the materials have been adjusted to the needs of the training 
participants with no any experience in joining training before. The materials of the job training were the new materials for them. Kaswan (2013:109) explained that the training materials given to the employees should be relevant to their job and task. In addition, the materials must reflect the work environment, including: physical environment, intellectual environment, and emotional environment where the training is held.

The training materials of handicraft consist of two: (1) learning material and learning; and (2) Material of basic skill in handicraft in the field of waste recycling. Those tow materials were structured by the experts based on their own field. The learning material and learning were given to the employees of ECO Green Park with a consideration that the employees have not had any knowledge about how to learn and how to teach. Meanwhile, the material of basic skill of handicraft that has been taught was adjusted to the environmental condition in the training place. Kamil (2010:161) mentions that the training material must be adjusted to the needs of learning, interest, and criteria of the training participants. Finally, this will have a positive impact on the training output (Putri, 2009).

Training Facilities: The facilities of the training at ECO Green Park, Kota Batu show that 48 participants (73.8\%) viewed that was categorized good and 17 participants $(26.2 \%)$ viewed it fair (Table 2). These results were supported by the condition of the class, the temperature management in room, equipment used, and the good and comfortable condition of the materials. However, the training facilities should be more improved to obtain a good output from the training.

Daryanto, et al. (2014:120) stated that the facilities in the form of classroom, temperature management in room, equipment used in training, and materials were the essential components in determining the success of a research. It means that if the facilities have been well planned and prepared, it will be one of the determinants of the success of training. The expectation from the improvement in facilities is to enhance the process quality as planned (Tambunan, 2013).

Strategy in Delivering the Training Materials: Table 2 shows that 53 participants (81.6\%) in general had a notion that the delivery of the materials at ECO Green Park, Kota Batu was good and 12 (18.4\%) viewed it good. These results were supported by the indicators of training method, training media and training technique.

The training method used has been adjusted with the situation and the needs; those are fulfilling the minimal condition to create learning effective. Cascio (In Kaswan, 2013:180) mentions that the minimum condition refers to a method that can give motivation, implement skill, provide an opportunity for the training participants to actively participate, given suggestion for reinforcing the participants and provide the feedback. Salinding (2011) also explained that a training method of positive and significant on the skill and knowledge improvement impacted towards the employees due to the appropriateness of the training method with the concept and needs for training.

Whereas, media used in this training were LCD projector. The media in the form of handout also was prepared by the trainer to be given to the training participants for facilitating the learning process. Learning media is a media that cannot be separated during the learning process in which the media plays an essential role and as the creative attempts to create the experience that can educate the learners to have a qualified output (Asyhar, 2012:27). Aligahni (2009) explained that learning media in training becomes one of the supporting factors for the effectiveness of the training, meaning if the learning media in training work well, it can enhance the work performance of the employees.

Whilst, the technique of training was focused on the trainer and training schedule. The trainers in this training were the lecturers that have many experiences in the field of education and skill in handicraft. Meanwhile, the schedule has been consulted with the Management of ECO Green Park for matching the planned schedule and the work hours of the employees. Mangkunegara (2011:51) argued that one of the essential components in training is trainer. That is why a trainer must be an expert that has an adequate qualification (professional). Faraditha (2013), also mentioned that $83.2 \%$ of the improvement of the employees' quality were influenced by a number of variables, including trainer, training materials, training facilities and the duration of the training.

Evaluation of Training Program: Table 2 shows that in general 58 participants (89.1\%) viewed that the evaluation of a training program at ECO Green Park, Kota Batu was in the category very good and 7 
participants (10.9\%) were in category good. This result was supported by the following indicators: (1) reaction, in general (81.8\%), was in the category good (2) learning, in general (91.13\%) was included in the category very good, (3) behavior, in common (90.5\%), was in the category very good and (4) the result of the respondents of the training in general $(93.2 \%)$ was in the category very good.

The model of evaluation of this training program was the Kirkpatrick model. It was suitable to be applied due to it found, how the response of the training participants, the improvement of competence (cognitive, affective and psychomotor), the attitude change in post-training were, what implementation that can be obtained during the training in the workplace, as well as to what extent the training conducted can provide an impact towards the enhancement of work performance of the employees (Kaswan, 2013). Handoyo \& Setiawan (2014) mentioned that the evaluation of Kirkpatrick Model was suitable to be applied in evaluating the training program and to reveal the data of reaction, learning, behavior, and results that had a good category. Rouse (2011) also saying that the Kirkpatrick model emphasized on the evaluation at the level of reaction, learning, attitude, and output in which the model of evaluation of the training was more focused on the condition required to transfer knowledge and skill learned in the application of job training.

\section{Conclusion and Implications}

Based on the research results, it can be concluded that the application of the model of lesson study based handicraft job training reveals a need of the employees for the training materials to support their job, the importance of facilities in the form of the sufficient classroom, and the interior in the position of chairs supported by the management of air temperature. In addition, the strategy in delivering the training material, particularly about the training method, training media, and training technique is needed to be concerned with learning. The evaluation of the training program using the Kirkpatrick model with 4 phases of evaluation includes (1) reaction, (2) learning, (3) behavior, and (4) result are highly necessary to measure the effectiveness of the training program.

The management needs to increase the competence of employees by providing training for the renewal of knowledge, attitudes, and skills of employees. If Training done on a regular basis, so this can improve employee performance that will impact on quality of service to visitors. Increased employee competencies can also be given through education and training directly from superiors to subordinates by providing two-way communication. The existence of good feedback will be able to have a positive impact on employee performance is supported by a conducive working environment. While trainees should further increase the desire to acquire knowledge and skills not only of the training provided, but also with other ways.

Finally, the expectation that training will be an enhancement in the work performance of the employees that will impact on the improvement of service quality towards the visitors at ECO Green Park. Due to this study is a first-time training that is applied in a place-based tourisms' education, so that future studies might take the model of training focus on the development of manufacture of guide books of learning materials that are implemented in a training in order to support the establishment of a better employee competence and appropriate.

\section{References}

Alighani, A. (2009). Pengaruh Pelatihandan Motivasiterhadap Kinerja Widyaiswara: Studipada Pusat Pengembangandan Pemberdayaan Pendidikdan Tenaga Kependidikanserta Lembaga Penjaminan Mutu Pendidikandi ProvinsiJawa Barat. Retrieved fromhttp://repository.upi.edu/8656/

Ameeq, U. A. \& Hanif, F. (2013). Impact of training on employee's development and performance in hotel industry of Lahore, Pakistan. Journal of Business Studies Quarterly. 4(4): 68-82.

Asyhar \& Rayandra (2012). Kreatif Mengembangkan Media Pembelajaran, Jakarta: Raferensi Jakarta.

Australian National Training Authority (ANTA). 2004. Fully on the Job Training Experiences and Steps Ahead. Australia: National Centre for Vocational Education Research (NCVER). Retrieved fromhttp: //www.meester-gezel.nl/doc/OJT_Training_on_the_job .pdf

Carrier, S. J. (2011). Implementing and Integrating Effective Teaching Strategies Including Features of Lesson Study in an Elementary Science Methods Course. The Teacher Educator. 46(2): 145-160. DOI: $10.1080 / 08878730.2011 .552666$.

Daryanto, Bintoro, Setyobudi, \& Ismanto (2014). Manajemen Diklat, Yogyakarta: Gava Media.

Demir, K., Czerniak, C. M., Hart, L. C. (2013). Context. Journal of College Science Teaching. 42(4): 22-27. 
Direktorat Perguruan Tinggi Tahun 2008 tentang Panduan Pelaksanaan Lesson Study di LPTK. Retrieved fromhttp://acenale.files.wordpress.com/2011/04/panduan-pelaksa-naan.doc

Enget, Fudail, B. S., Lazim, M., Karyono, S., Sudarmanto, E., Wibowo, E., Supriyono F. X., Suharta, W., Winarto, Gunawan. (2008). Kriya Kayu untuk Sekolah Menengah Kejuruan(Soehardi, M, Ed). Retrieved fromhttp://bse.mahoni.com/data/SMK_10/Kriya_Kayu_Jilid_1Kelas_10Enget_2008.pdf

Faradhita, Ariza, Luky. (2013). Program Training (Pelatihan) terhadap Kualitas Karyawan. E-Jurnal Administrasi Bisnis. 1(1): 1-7.

Gun, B.S \& Davies, M. (2008). Guidelines for Successful Competency and Training Management. Risktec Solutions, Ltd. Retrieved fromhttp://www.risktec.co.uk/ media/47873/competency\%20 and\%20training\%20management\%20guidelines\%203.1pdf.pdf

Handoyo, Steven \& Setiawan, Roy. 2014. Evaluasi Pelatihan Tenaga Mekanik pada PT United Motors Center Surabaya. AGORA. 2(2): 1-10.

$\mathrm{Hu}$, Suhong. 2004. Design an Effective Model for Training The Trainers.Retrieved fromhttp://www.cek.ef.uni-lj.si/magister/hu462.pdf

ILO. (2010). A skilled workforce for strong, sustainable and balanced growth: A G20 training strategy.International Labour Office, Geneva: ILO publications. Retrieved from http://www.ilo.org/publns

Kamil, Mustofa (2010). Model Pendidikan dan Pelatihan, Bandung: Alfabeta.

Kaswan. (2013). Pelatihan dan Pengembangan untuk Meningkatkan Kinerja SDM. Bandung: Alfabeta.

Mangkunegaran, Anwar, Prabu. (2011). Perencanaan dan Pengembangan Sumber Daya Manusia (Revised Edition), Bandung: Refika Aditama.

Muzaffar, M. U., Salamat, H. S. H., and Ali, H. S. M. M. 2012. Impact of Trainings on Employees Outcome in IT Sector Pakistan. Global Journal of Management and Business Research. 12(6): 20-26.

PeraturanPemerintah No.31 tahun 2006 tentangSistemPelatihanKerjaNasional. PelatihanKerja. Retrieved fromhttp://luk.staff.ugm.ac.id/atur/PP31-2006.pdf.

Putri, Ratu, Ilma, Indra. (2009). EfekPotensialPelatihan PMRI terhadap Guru-Guru Matematika di Palembang. Jurnal Pendidikan Matematika. 3(2): 85-91.

Retnaningsih, E., Preadhatya, W., Trisnaningsih, $\quad$ R. $\quad$ (2010). PemanfaatanPlastikdanBotolBekasSebagaiKerajinanTangan yang Menarik. Semarang: UniversitasNegeri Semarang.Retrieved fromhttp://gs2.ukm.unnes.ac.id/wpconten/uploads/2012/09-/pkmk-EK-Plastik-bekas.pdf

Riyati, Siti. (2007). SistemPembinaanProfesional Guru Pendidikan IPA Melalui Lesson Study.Retrieved fromhttp://file.upi.edu/Direktori/FPMIPA/JUR._PEND._BIO-LOGI/19640-9281989012SITI_SRIYATI/Kumpulan_artikel_5/Lesson_Study-.pdf

Rouse, Donald, Nick. 2011. Employing Kirkpatrick's Evaluation Framework to Determine the Effectiveness of Health Information Management Courses and Programs. Journal Perspect Health in of Management Spring. 5(8): 1-5.

Salmah, Ninin, Non, \& Ayu (2012). Pengaruh $\quad$ Program PelatihandanPengembanganKaryawanterhadapKompetensiKaryawanpada PT. Muba Electric Power Sekayu. JurnalEkonomidanInformasiAkuntansi (Jenius), 2 (3): 278-290.

Salinding, Rony. (2011). AnalisisPengaruhPelatihanterhadapProduktivitasKerjaKaryawanpada PT. ErajayaSwasembadaCabang Makassar.Retrieved fromhttp://repository.unhas.ac.id/bitstream/handle/123456789/1214/RONY\%20SALINDING.PD F?sequence $=1$

Setyoko, Adnan. (2013). BarangBekasSebagaiBahanBerkaryaSeniKriya Di Komunitas TUK Salatiga: Proses Dan NilaiEstetis. Journal of Visual Arts. 1(1): 1-6.

StandarNasionalPendidikan. (2006).StandarNasionalPendidikan. Jakarta: AsaMandiri.

Susilo, Herawati. (2013). Lesson Study sebagaiSaranaMeningkatkanKompetensiPendidik. Retrieved fromhttp://sttaletheia.ac.id/wp-content/uploads/2013/07/Lesson-Study-Sebagai-SaranaMeningkatkan-Kompetensi-Pendidik-herawati.pdf

Sultana, A., Irum, S., Ahmed, K., Mehmood, N. (2012). Impact of training on employee performance: a study of telecommunication sector in Pakistan. Interdisciplinary journal of contemporary research in business. 4(6): 646-661.

Tambunan, Anggiat. (2013). PengaruhPelatihanterhadapPeningkatanKemampuanKaryawan: StudiKasuspada Program Pelatihan Computerized Numericai Control terhadapKemampuanKaryawan Unit Profit Center AIPCM PT. Dirgantara Indonesia, Tahun 2011.Retrieved fromhttp://repository.upi.edu/853/

Undang-Undang RI No. 20 Tahun 2003 tentangSistemPendidikanNasional. KetentuanUmumPendidikan. Retrieved fromhttp://www.dikti.go.id/files/atur/UU20-2003Sisdiknas.pdf 
Utarini, R., Rusdiyana, Mufidah, Z. (2012). PemanfaatanLimbahDaunKeringMenjadiKerajinan Home Industri di Kota Malang. Malang: UniversitasNegeri Malang. Retrieved fromhttp://kemahasiswaan.um.ac.id/wp-conten/uploads/2010/04/pkm-ai-10-um-rachmapemanfaatan-limbah-daun-.pdf

Wahyono, E. H. Dan Sudarno, N. (2012). PengolahanSampahPlastik: Aneka KerajinandariSampahPlastik. Bogor: Yapeka. Retrieved fromhttp://cibodas-itto.org/wp-conten/uploads/2013/04/BukuPengelolaan-Sampah-Plastik-ITTO-Yapeka.pdf

methods. Journal of social Studies Research, Conference Proceedings. 1(1): 104-112.

Yoshida, Makoto. (2002). Overview of Lesson Study in Japan. Retrieved fromhttp://www.rbs.org/SiteData/docs/yoshidaoverview/aeafddf638d3bd67526570d5b4889ae0 /yoshidaoverview.pdf 